\title{
プラズマ溶射に用いられる粒子を含む高温噴流の熱流動解析*
}

\author{
南 聖 源*1, 大久保 雅 章*2 \\ 西山秀 哉*3, 神山新 ${ }^{* 3}$
}

\section{Numerical Analysis of Heat Transfer and Fluid Flow on High-Temperature Jet Including Particles in Plasma Spraying}

\author{
Seong-Won NAM, Masaaki OKUBO, \\ Hideya NISHIYAMA and Shin-ichi KAMIYAMA
}

\begin{abstract}
A numerical analysis is conducted on heat transfer and fluid flow of a high-temperature jet including particles in plasma spraying, which is utilized to produce heatresistant, anticorrosion and abrasion-resistant coatings. Finite heat conduction analysis is adopted to consider the internal temperature distribution in a particle and further, the forces induced by the relative motion are added to the Stokes drag term in the equation of particle motion. The comparison between Lagrangian and Eulerian approaches to the evolution of velocity and temperature of alumina particles is presented. The equation of particle motion is calculated using the 4 th order Runge-Kutta method, as is the residence time of particles in each calculation cell of the flow field using the bisectional method which was developed by us. Particles of three different materials $\left(\mathrm{Al}_{2} \mathrm{O}_{3}, \mathrm{Ni}, \mathrm{W}\right)$ are considered and the coupling between two phases is examined on the basis of the momentum and energy exchange.
\end{abstract}

Key Words: Multi-phase Flow, Jet, Axisymmetric Flow, Heat Transfer, Numerical Analysis, Particles, Plasma Spraying

\section{1. 緒言}

固体の粒子または液滴を含む二相流はいろいろな産 業分野で見受けられる。その例としてはエンジン内の 噴射, 粉体の空気輸送、ロケット推進, などが挙げら れる。 また, 近年, 産業の発達に伴って, 高温, 腐食, 摩耗の環境でも耐えられる機能性皮膜で被覆された工 業用材料の必要性が高まってきており，その創製プロ セスの一つとしてプラズマ溶射法が用いられている。 プラズマ溶射プロセスは固気二相流の典型的な例であ り，装置の試作や実験および数值シミュレーションの 研究が活発に行われている．皮膜材料として注入され る微粒子の熱流動特性を明らかにすることはプラズマ 溶射の効率を左右する重要な因子であるが, 実験的に 求めることは非常な困難を伴うので数值シミュレーシ ヨンは必要不可欠である。流体相に対しては，希薄流 のアプローチが必要な減圧状態ではないかぎり連続体 としての解析が適用できる。一方, 粒子相に関しては

* 原稿受付 平成 4 年 11 月 17 日。

*1 正員, 東北大学大学院.

*2 正員, 東京工業大学原子炉工学研究所 ( 10152 東京都目黒区 大岡山 2-12-1) (東北大学流体科学研究所).

*3 正員, 東北大学流体科学研究所 $(\mathbf{E 9 8 0}$ 仙台市青葉区片平 21-1).
オイラー法およびラグランジュ法での解析がそれぞれ の長所をもっており，おの扔のの研究目的に応じて用 いられている。一般的にラグランジュ法では相変化を 伴う粒子の運動の計算が厳密に行えるという利点をも つ.また，この方法では混入される粒子が受ける流体 の乱流特性の評価は平均流を用いた扱いと確率論的な 扱いがあるが, 後者がその特性をよく表している(1). また, 粒子の体積分率が高くなった場合を対象に粒子 同士の相互作用を考慮した解析も行われている(2).さ らに, 粒子内の状態変化については粒子の直径が小さ い場合,一般に, 粒子内の温度は一様として粒子を集 中熱容量系として扱っているが，プラズマ溶射のよう に流動場の変化が激しく, 粒子の熱伝導率が比較的低 い場合には，その内部温度分布を考慮することは重要 である。

したがって, 本研究では粒子 1 個ずつの運動の追跡 が可能なラグランジュ法によりその熱流動特性を解析 し，既報(3) のオイラー法による結果との比較を行っ た。なお, 粒子の内部温度分布の計算には熱伝導方程 式を準定常近似で解く方法を用い, 流体から受ける乱 流特性の評価に確率論的な扱いを導入した。さらに流 体との相対速度に起因するせん断力, 回転揚力および 時間履歴を表す Basset 力の項を含む運動方程式を用 
いて速度および滞在時間の解析を行った。

\section{おもな 記 号}

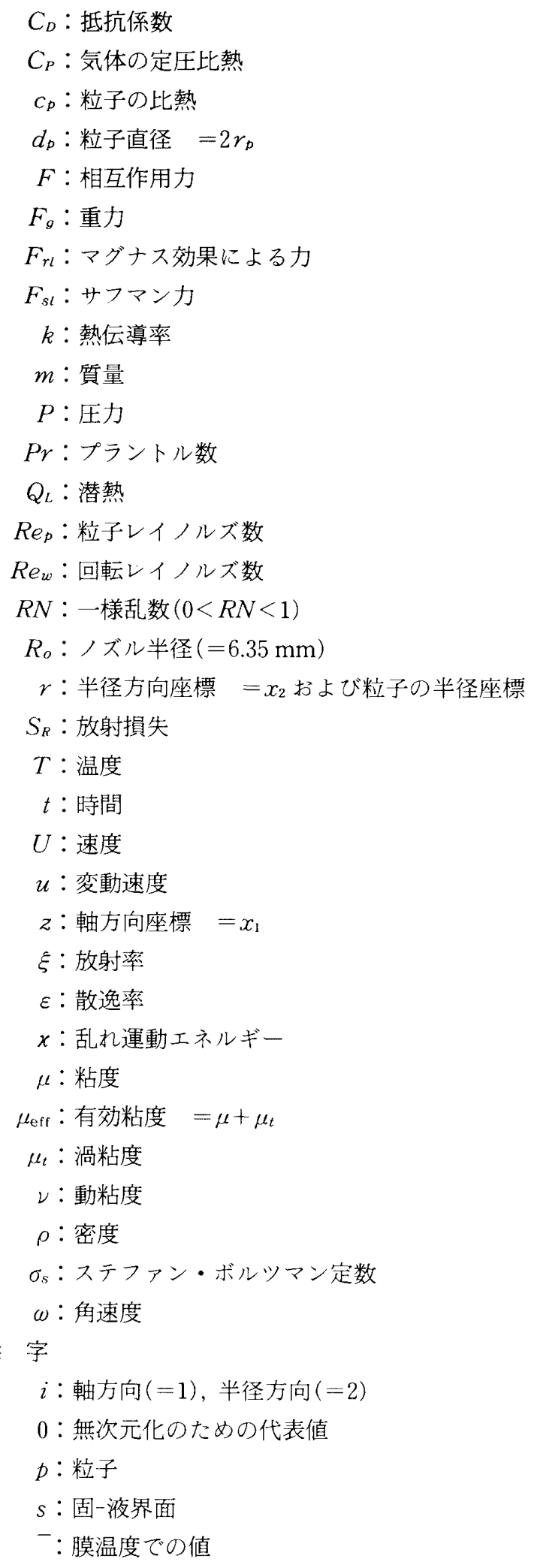

\section{2. 基 礎 式}

図 1 はプラズマ溶射の概略図で破線内部は軸対称の
計算領域である。気体はアルゴンガス，粒子はアルミ ナ $\left(\mathrm{Al}_{2} \mathrm{O}_{3}\right)$, ニッケル $(\mathrm{Ni})$, タングスタン $(\mathrm{W}) を$ 想定 し, 常温での密度はおのおの $3740,8900,19250 \mathrm{~kg} /$ $\mathrm{m}^{3}$ である。

アルゴンガスの流れを二次元定常流とした場合，そ の連続, 運動方程式は次式により与えられる。

$$
\begin{aligned}
& \left(\rho U_{j}\right)_{, j}=0 \\
& \left(\rho U_{j} U_{i}\right)_{, j}=-P_{, i}+\left[\mu_{\mathrm{eff}}\left(U_{i, j}+U_{j, i}\right)\right]_{, j} \\
& -\frac{2}{3}\left(\mu_{\mathrm{eff}} U_{j, j}\right)_{, i}-F_{i}
\end{aligned}
$$

二相間の相互作用力は, 着目しているコントロールボ リュームでの粒子の通過前後の粒子の慣性力を基に評 価する方法がある(4).しかし，この方法では粒子が大 きい場合, 粒子の速度が終速度に達しても流体の速度 とは差があり，このような場合には二相間の相互作用 は依然存在するが通過前後の慣性力の差はないので相 互作用力がうまく評洒されないという欠点がある。一 方, 粒子の粘性抵抗のみ考慮する方法もあるが(5)，後 述するように本計算では粒子の運動方程式において粘 性抵抗以外に他の項も考慮しているのでこの方法にも 無理がある.したがって, 本研究では二相間の相互作 用力を粒子群の運動量通過量の時間的変化により評価 した次式で与える。

$$
F_{i}=\frac{d v \rho U_{i}-\sum_{k=1}^{n} \frac{\pi}{6} d_{p}^{3} \rho_{p} U_{p i}^{k}}{d t}
$$

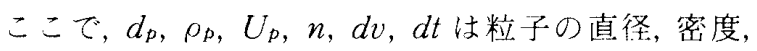
速度, 含有粒子数, コントロールボリューム, 時間刻 みである。

種々の乱流現象の予測に用いられる実用的な乱流モ

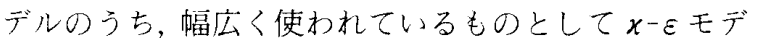
ルが挙げられる。二相流に対しては第 2 相の存在によ って乱流の構造が変化することが知られており,きま

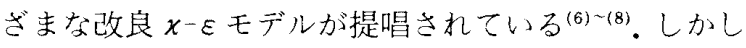
ながら，固体粒子または液滴を含む二相流をラグラン ジュアプローチで报う場合，数值計算で使われるもの 沙ないこともあって本研究では従来の $x$ - $モ$ モデル

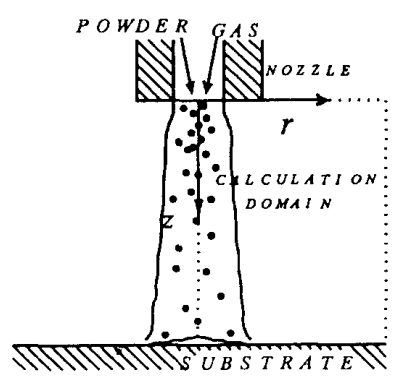

図 1 プラズマ溶射の概略 
を使うことにした(9).

$$
\begin{aligned}
& \left(\rho U_{j} \phi\right)_{, j}=\left(\left(\mu+\frac{\mu_{t}}{\sigma_{\phi}}\right) \phi_{, j}\right)_{, j}+S \\
& \left\{\begin{array}{l}
S=G-\rho \varepsilon \quad \text { if } \phi=\chi, \\
S=c_{1} \frac{\varepsilon}{\chi} G-c_{2} \frac{\varepsilon^{2}}{\chi} \rho \quad \text { if } \phi=\varepsilon
\end{array}\right. \\
& G=\mu_{t} U_{k, l}\left(U_{k, l}+U_{l, k}\right) \\
& \mu_{t}=c_{u} \rho \frac{\chi^{2}}{\varepsilon} \quad \ldots \ldots \ldots \ldots \ldots \ldots \ldots \ldots \ldots \ldots \ldots \ldots \ldots \ldots \ldots
\end{aligned}
$$

ここで, $\mu_{t}$ は渦粘度であり, $x-\varepsilon$ モデルでの定数は

$c_{1}=1.44, c_{2}=1.92, c_{\mu}=0.09$,

$\sigma_{\kappa}=1.0, \sigma_{\varepsilon}=1.3$

とした.

流体のエネルギー保存則は次のように表せる.

$$
\left(\rho U_{j} T\right)_{, j}=\left(\frac{k}{C_{P}} T_{, j}\right)_{j}-\frac{S_{R}}{C_{P}}-F_{T}
$$

ここで, $T$ は流体の温度, $S_{R}$ は放射損失で Evansら の実験データ(10) から温度の関数として与えた。また， $F_{T}$ は相互作用項で式 (3)で $U_{i}, U_{p i}$ のかわりに $T$, $T_{p}$ を用いて与えられる。

一方, 静止流体での球形粒子の運動方程式は Basset-Boussinesq-Oseenによって導かれたが, 流体と の相対速度がある場合の式は Tchenによって拡張さ れた(11).さらに，せん断流中で粒子が受ける Saffman 力, 回転揚力 (Magnus 力)の項を加えると粒子の運動 方程式は以下のようになる。

$$
\begin{gathered}
m_{p} \frac{d U_{p i}}{d t}=3 \pi \mu d_{p}\left(U_{i}-U_{p_{i}}\right)+m \frac{D U_{i}}{D t} \\
+F_{g i}+F_{r l i}+F_{s l i}+\frac{1}{2} m \frac{d}{d t}\left(U_{i}-U_{p i}\right) \\
+\frac{3}{2} d_{p}^{2} \sqrt{\pi \rho \mu} \int_{t_{0}}^{t} \frac{\frac{d}{d t^{\prime}}\left(U_{i}-U_{p i}\right)}{\sqrt{t-t}} d t^{\prime} \cdots \cdots \cdots \\
\text { ここで, } m=\frac{\pi}{6} \rho d_{p}^{3} \text { であり } \\
\frac{D U_{i}}{D t}=U_{i, t}+U_{j} U_{i, j}, \frac{d U_{i}}{d t}=U_{i, t}+U_{p j} U_{i, j}
\end{gathered}
$$

と定義する。式（８）の右辺の各項はそれぞれ Stokes 抵抗力, 压力こう配による力, 重力, 回転揚力, Saffman力, 付加質量に作用する慣性力および非定常 運動をする粒子に働くBasset 力の項である. Stokes 抵抗力に対する各項の相対的オーダは $A=r_{p}^{2} / L_{o \nu}$ と するとおのおの $O\left(A U_{o}\right), O\left(A g L_{o} \rho_{p} / U_{o} \rho\right)$, $O\left(A L_{o} \omega_{p}\right), O\left(A U_{o}\right)^{0.5}, O\left(A U_{o}\right), O\left(A U_{o}\right)^{0.5}$ で, ᄂ たがって基板のごく近傍を除き $F_{s l}, F_{r l} \gg$ 圧力こう 配による項, 仮想付加質量項, $F_{g} \simeq$ 仮想付加質量項 $\rho_{p} / \rho$ が成り立つことがわかる.なお, 式（9)の第 1 式 と第 2 式は $\left|U-U_{p}\right| \ll|U|$ の条件ではほとんど等価な
式となる．時間履歴を表すBasset 力の積分項は時間 刻み $d t$ が小さい仮定の下で次式の形で近似でき る(12).

$$
\sum_{i=1}^{n}\left(\frac{d U_{p}}{d t}-U_{p} \frac{d U}{d x_{1}}\right)\left(\sqrt{t^{n}-t^{i-1}}-\sqrt{t^{n}-t^{i}}\right)
$$

次式で与える速度こう配によるSaffman力は低粒子 レイノルズ数に対して導かれたが, 高レイノルズ数に 対しても適用できることが確認された(13).

$$
F_{s l 2}=1.615 d_{p}^{2} \sqrt{\rho \mu\left|\frac{d U_{1}}{d x_{2}}\right|}\left(U-U_{p}\right)_{1} \cdots
$$

回転揚力 $F_{r l i}$ は Rubinow-Kellerによって解析され たもの (14)を Matsumoto-Saito ${ }^{(15)}$ が実験を基に修正 したが，彼らの実験における流速は本計算条件に比べ てかなり小さいのでRubinowの式において相対速度 および角速度を考慮し, 次式により与える。

$F_{r l i}=\pi d_{p}^{3} \rho \epsilon_{i j k}\left(\omega-\omega_{p}\right)_{j}\left(U-U_{p}\right)_{k} / 8 \cdot$

ここで $\epsilon_{i j k}$ は交代記号である.

一方, 粒子の角運動量保存式は広い範囲の粒子回転

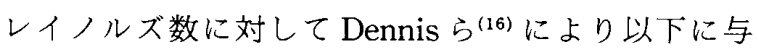
えられた。

$$
\begin{aligned}
& I \frac{d \omega_{p}}{d t}=-\frac{1}{2} \rho \gamma_{p}^{2}\left(\omega-\omega_{p}\right)\left|\omega-\omega_{p}\right| \\
& \quad \times\left(\frac{\alpha}{\operatorname{Re}_{w}^{1 / 2}}+\frac{\beta}{R e_{w}}\right) \ldots \ldots \ldots \ldots \ldots . . .
\end{aligned}
$$

ここで, $I$ は粒子の慣性モーメント, $\alpha, \beta$ は定数, $R e_{w}=\left|\omega-\omega_{p}\right| r_{p}^{2} \rho / \mu$ は回転レイノルズ数である. 球形 粒子に対寸る抵抗係数 $C_{D}$ はレイノルズ数の範囲によ り次のように与えられる(17).

$$
C_{D}= \begin{cases}\frac{24}{\operatorname{Re}_{p}}\left(1+\frac{1}{6} R e_{p}^{1 / 3}\right) & R e_{p}<1000 \\ 0.44 & R e_{p} \geq 1000\end{cases}
$$

$$
\begin{aligned}
& \operatorname{Re}_{p}=\frac{\rho d_{p}\left|\tilde{U}_{i}-U_{p_{i}}\right|}{\mu} \\
& \tilde{U}_{i}=U_{i}+u_{i} \cdots \cdots \cdots \cdots
\end{aligned}
$$

粒子が気体から受ける乱流特性を評価するために $u_{i}$ は次式のように平均二乗偏差 $(2 / 3) x$ の等方正規分布 からランダムに抽出した(18).

$$
f\left(u_{i}\right)=\sqrt{\frac{3}{4 \pi x} e^{-3\left(u_{i}\right)^{2} / 4 \kappa}}
$$

$u_{i}$ は次式のサンプルから求められる。

$$
\left.\begin{array}{l}
u_{1}=\sqrt{-\frac{4}{3} x(\ln R N)} \cos (2 \pi R N) \\
u_{2}=\sqrt{-\frac{4}{3} x(\ln R N)} \sin (2 \pi R N)
\end{array}\right\}
$$

ここで, $R N$ は一様乱数で $(0<R N<1)$ の範囲の值を もつ. 
流れ場に混入された粒子内の温度分布を決定する対 流一熱伝導方程式は次のように与えられる。

$$
\begin{aligned}
& \rho_{p} c_{p} \frac{\partial T}{\partial t}=\frac{1}{r^{2}} \frac{\partial}{\partial r}\left(r^{2} k_{p} \frac{\partial T_{p}}{\partial r}\right) \ldots \ldots . . . \\
& k_{p} \frac{\partial T_{p}}{\partial r}=h\left(T_{\infty}-T_{p}\right)+\sigma_{s} \xi\left(T_{p}^{4}-T_{o}^{4}\right)
\end{aligned}
$$

ここで, $r$ は粒子の半径座標であり, また, 高温流で の球の熱伝達率 $h$ は膜温度 $T=\frac{T+T_{p}}{2}$ での值 $\bar{k}$, テで次式のように与えられる(19).

$$
h=\frac{\bar{k}}{d_{p}}\left(2+0.6 \operatorname{Re}_{p}^{1 / 2} \operatorname{Pr}^{1 / 3}\right)\left(\frac{\bar{\nu}}{\nu}\right)^{0.15}
$$

また, 粒子の中心部と溶隔時の粒子内部の固-液界面 $r_{s}$ での条件は次のようになる。

$$
\begin{aligned}
& \frac{\partial T_{p}}{\partial r}(0, t)=0 \\
& \left.k_{p} \frac{\partial T_{p}}{\partial r}\right|_{r_{s}=r_{s}(t)-0}=\left.k_{p} \frac{\partial T_{p}}{\partial r}\right|_{r_{s}} \\
& -Q_{L} \cdots
\end{aligned}
$$

ここで，QL 法での粒子の速度, 温度および滞在時間を計算する流 れ図でその手順は以下のようになる。

コントロールボリュームについて離散化する方 法(20)を用いて計算した流体相の $U, T$ を入力デー夕 として四次のルンゲ・クッタ解法の独立変数 $t$ の上限 值として任意に大きい值を設定する。このとき，上限 值は粒子がコントロールボリュームを通過するのに要 する時間より相当大きくとるべきであるが大きすぎる と計算時間もそれにつれて長くなる。二分法の考えに

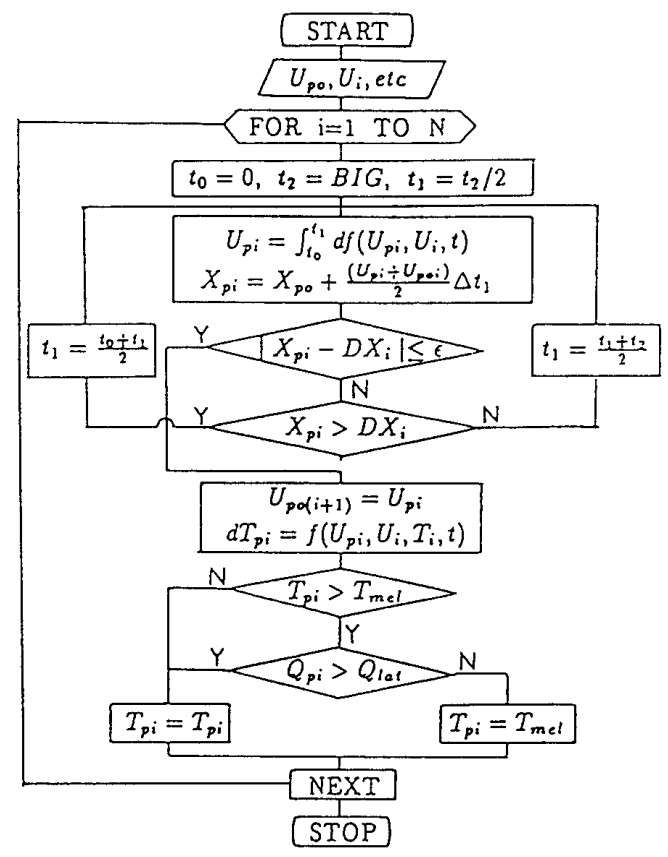

図 2 計算の流礼図
基づいて $t_{1}$ までの粒子の移動距離がセルの幅と一致 するまで $t_{1}$ を変更しながら計算する。ただし， $t_{0}$ は零 に固定されている。求吼た速度は次の初期速度に なり，時間 $t_{1}$ の間の粒子の温度上昇值を求めて正しい 温度の判定を潜熱を用いて行う。これらの手順を粒子 が基板に到達するまで各コントロールボリュームに対 して実行する。

\section{3. 結果および考察}

計算は既報 ${ }^{(3)}$ の結果と比較するため，基板がノズル からノズル半径の15.748倍離れている場合を扱い, 噴流軸上を移動する粒子のみについて行った。その他 の条件は次のとおりである. ノズル出口速度 $U_{o}=$ $223.3 \mathrm{~m} / \mathrm{s}$, 出口温度 $T_{o}=10000 \mathrm{~K}$, ノズルに流入す るアルゴンガスの流量 $786.6 \times 10^{-6} \mathrm{~m}^{3} / \mathrm{s}$ ，その流量に 対する注入粒子の体積分率 $10^{-5}$. 図 3，4 仗それぞれア ルミナ粒子(直径 $15,30 \mu \mathrm{m}$ )の噴流軸上での粒子速度

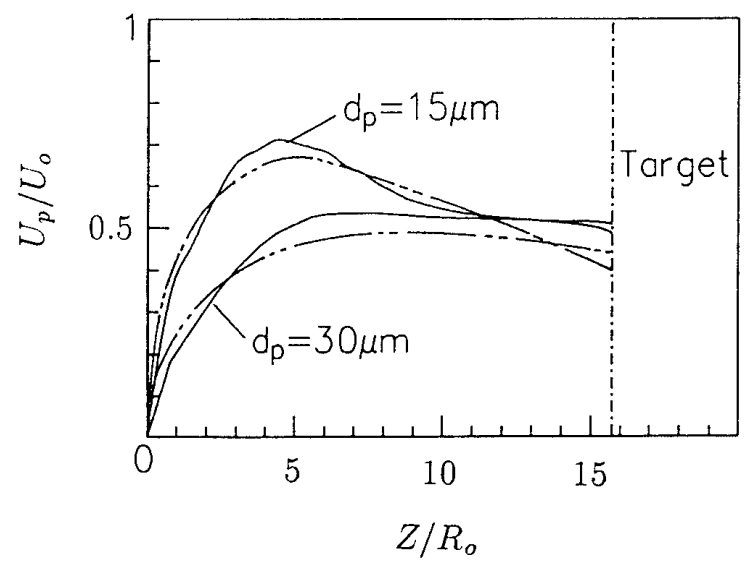

図 3 軸上の速度変化の両アプローチの比較 (ラグランジュ法：一,オイラー法：一、一)

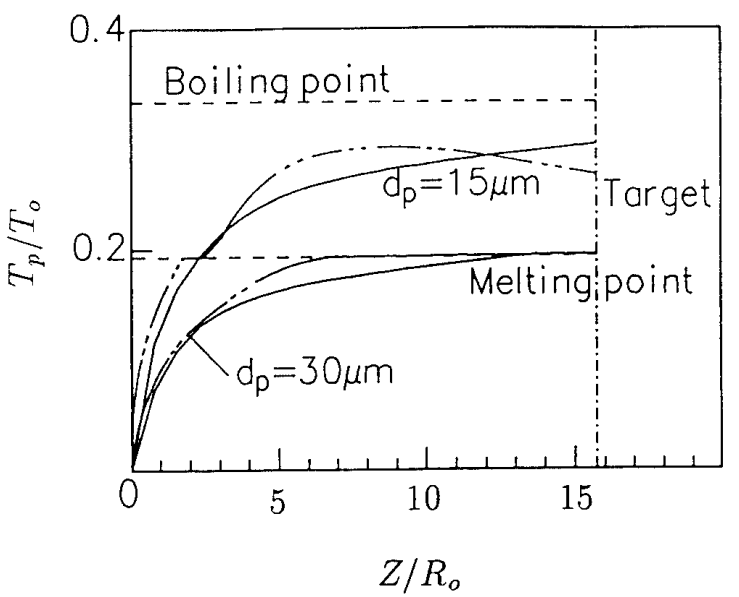

図 4 温度変化の両アプローチの比較 (ラグランジュ法：一,才イラー法：一・五) 
と粒子内平均温度の変化を既報のオイラー法の結果と 比較して示したものである。縦および横軸の值はノズ ル出口の流体の速度 $U_{o}$, 温度 $T_{0}$ およびノズルの半 径 $R_{o}$ でおのおの無次元化して示している. 両解析法 は定性的および定量的にもよく一致している. 図 3 に よると粒子径が小さい場合, ノズル出口の近傍で粒子 は急速に加速されるが慣性力が小さく, 流体の速度の 変化の影響を受けやすいため基板近傍の低流速領域で は急激にその速度が減少する。速度変化の細かい摇ら ぎは式(16)の変動速度 $u_{i}$ によるもので小さい粒子ほ ど流体の乱流特性に追従しやすいため, その值が大き くなっている. 一方, 大きい粒子はある程度まで加速 された後, 終速度に達して基板に到達する.また図 4 においてオイラー法では, 粒子の初期温度 $293 \mathrm{~K}$ 粒径 が $15 \mu \mathrm{m}$ の場合に, 粒子の隔点すなわち相変化点にお いて曲線が横軸と平行となるが,これは粒子内部の温 度を一様と仮定して計算したことに起因するもので， 内部の温度分布を考慮し, 粒子内の平均温度を表示し た本計算結果においてはこのような部分は見られな い.なお, 粒子の運動に及ぼす Saffman力, Basset 力 抢よび Magnus 力による作用はオーダ評価からもわ かるようにStokes 抵抗力に比べてかなり小さいが, 本研究のような詳細な粒子の熱流動特性を求める場合 には考慮するべきものと考えられる。

図 5,6 は粒径が $10 \mu \mathrm{m}$ と $50 \mu \mathrm{m}$ の場合についてノ ズル出口における粒子の注入速度を変化させた場合の
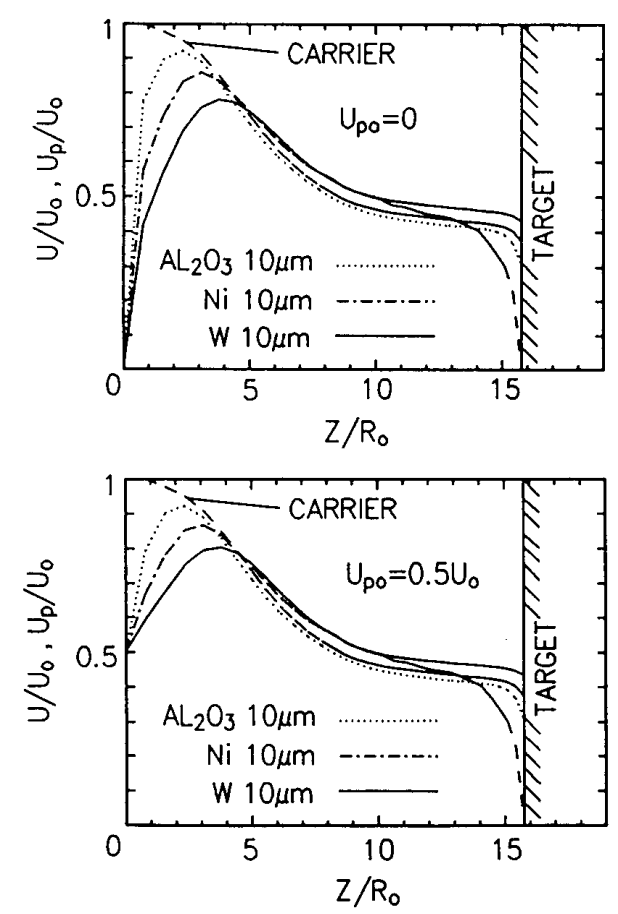

図 5 粒子注入速度による粒子速度変化 $(10 \mu \mathrm{m})$
軸上での粒子およびガスの軸方向速度の変化を示した ものである. 図 5 より，10 $\mathrm{m}$ の小さい粒子は注入速 度および材質によらずほほ同じ速度で基板に到達する が, 図 6 より, 密度が大きいタングステン粒径 $50 \mu \mathrm{m}$ の大きい粒子の場合は注入速度によって到達時の速度 にかなりの差が生じることがわかる。すなわち $50 \mu \mathrm{m}$ の場合, 注入速度が零のときの粒子がもつ慣性力はお もに流体によって加速されることによるもので, 材質 間の密度差によってその大小が生じる。また, 注入速 度が $0.5 U_{o}$ の場合には粒子はもともと相当大きな慣 性力をもっており，ほとんどその大きさを保ったまま 基板に到達する。

図 7 はアルミナ粒子の内部温度分布の計算結果であ る.ここで $T_{c}$ は粒子中心の温度である.図 7 からわか るように粒子の直径が小さい場合でもアルミナの比較 的低い熱伝導率, 短い滞在時間のために表面と中心と の温度差は $60 \mathrm{~K}$ 程度とかなり大きい. 粒径 $10 \mu \mathrm{m}$ の 場合, $z=10, z=15$ の位置では粒子が溶隔状態にある のでその温度差はただ表面だけにある。

粒径 $10 \mu \mathrm{m}$ の $\mathrm{Al}_{2} \mathrm{O}_{3}, \mathrm{Ni}, \mathrm{W}$ 各粒子内部の平均温度 の変化の計算結果を図 8 に表す。ここで $\mathrm{Al}_{2} \mathrm{O}_{3}, \mathrm{Ni}$, W 略号 A, N, W で表し, B.P およびM.Pはそれ ぞれ沸点, 隔点を表す。ノズル出口近傍では粒子と周 囲の気流間の相対速度が大きく, 粒子レイノルズ数が 大きいため式(21)からわかるように熱伝達率も増大す る.そのため, 大部分の温度上昇はノズル出口近傍で
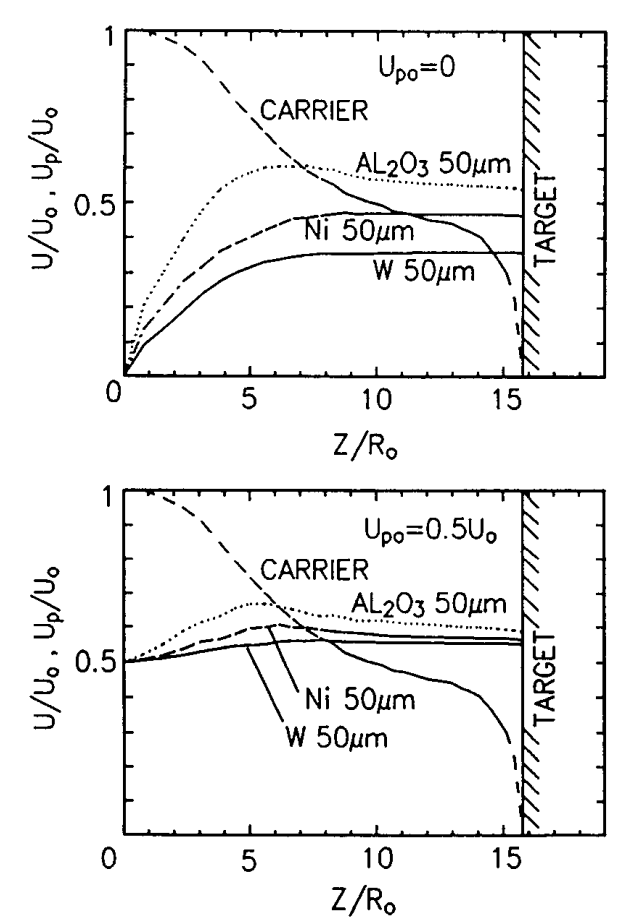

図 6 粒子注入速度による粒子速度変化 $(50 \mu \mathrm{m})$ 


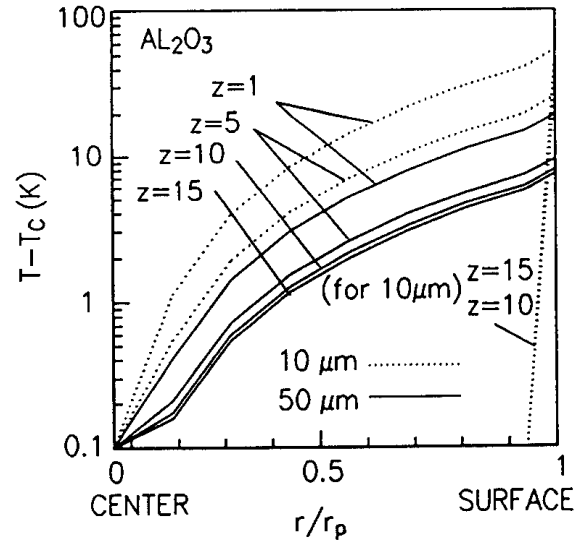

図 7 粒子の内部温度分布

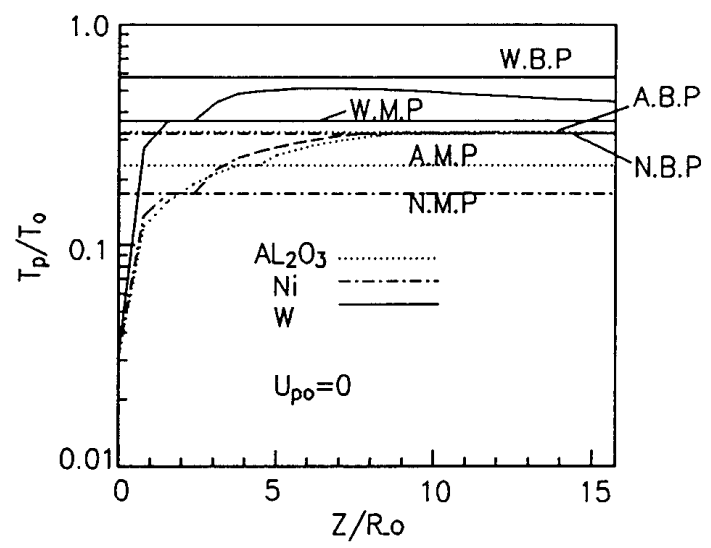

図 8 粒子の平均温度分布 $\left(\mathrm{Al}_{2} \mathrm{O}_{3}, \mathrm{Ni}, \mathrm{W}\right)$

起こる.

図 9 は基板との距離 $100 \mathrm{~mm}$ の場合の粒子の材質 および注入速度を変えた場合の混入粒子の気体中の無 次元表示の滞在時間を示したものである。図 9 から， 注入速度が零の場合, 粒子の直径が大きくなる程粒子 の滞在時間が長くなる。また, 粒子の種類による格差 も粒径にほぼ比例して広がるが入口から大きい慣性力 をもっている初期速度 $0.5 U_{0}$ の場合汶粒子の種類に よる差は小さい。これは流体より密度が何倍も大きい 粒子が一度大きな慣性力をもつと外部からの要因は粒 子の運動にほとんど影響を及ぼさなくなることを意味 している.

\section{4. 結論}

プラズマ溶射に用いられる粒子を含む高温噴流の熱 流動解析を粒子相にラグランジュ法を適用して行っ た。得られた扔もな結果をまとめると以下のようにな る.

（1）粒子の軸方向速度と平均温度に関してオイラ 一法とラグランジュ法の比較による解析結果は定性的

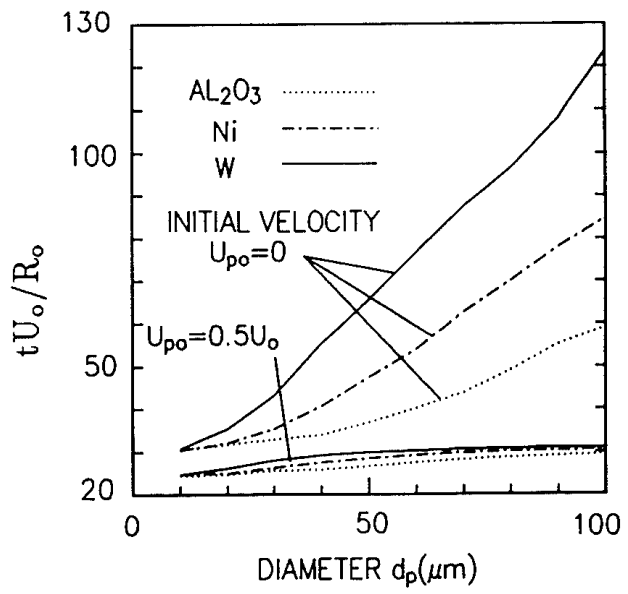

図 9 粒子の滞在時間

および定量的によく一致している.

（2）粒子径が小さい場合，ノズル出口の近傍で粒 子は急速に加速されるが, 流体の速度の変化の影響を 受けやすいため, 粒子は基板近傍の低流速域で急速に 減速する．大きい粒子はある程度まで加速された後， 終速度に達して基板に到達する。

（3）小さい粒子は注入速度およびその材質の密度 によらずほほ同じ速度で基板に到達するが, 密度, 粒 径が大きい粒子の場合は注入速度によって到達時の速 度にかなりの差が生じる。

（4）粒子の直径が小さい場合でも低い熱伝導率， 短い滞在時間のために粒子の表面と中心との温度差は かなり大きい。また，大部分の温度上昇はノズルの出 口近傍で生じる.

（5）プラズマ溶射の効率を左右する粒子の滞在時 間に関する粒子の材質，注入速度および粒径による変 化を明らかにした。

\section{文献}

(1) Shuen, J. S., ほか 3 名, AIAA J., 23(1985), 396

（2）田中・注か 2 名, 機論, 56-531, B (1990), 3210.

(3) 西山・ほか3名, 機論, 58-547, B(1992)，736。

(4) Crowe, C. T., ほか 2 名, Trans. ASME, J. Fluid Eng., 99 (1977), 325.

(5) Chen, C. P. and Wood, P. E., Can. J. Chem. Eng., 63 (1985), 349 .

(6) Elghobashi, S. E. and Abou-Arab, T. W., Phys. Fluids., 26 (1983), 931

(7) Rizk, M. A. and Elghobashi, S. E., Phys. Fluids, 28 (1985), 806.

(8) Melville, W. K. and Bray, K. N. C., Int. J. Heat Mass Transf., 22(1979), 279.

(9) Launder, B. E. and Spalding, D. B., Compnt. Methods Appl. Meth. Eng., 3(1974), 269.

(10) Evans, D. L. and Tankin, R. S., Phys. Fluids, 10(1967), 1137.

(11) Hinze, J. O., Turbulence, 2nd ed., (1975), 460, McGraw- 
Hill.

(12) Lucien, M. B., ほか 2 名, Proc. ASCE J. Hyd. Div., (1964), 149.

(13) Saffman, P. G., J. Fluid Mech., 22 (1965), 385.

(14) Rubinow, S. I. and Keller, J. B., J. Fluid Mech., 11 (1963), 447.

(15) Matsumoto, S. and Saito, S., J. Chem. Eng. Jpn., 31 (1970), 83.

(16) Dennis, S. C. R., ほか2名, J. Fluid Mech., 101(1980),
257.

(17) Gosman, A. D. and Ioannides, E., AIAA Paper, 810323(1981).

(18) Nam, S. W., ほか 3 名, Proc. 2nd JSME-KSME Thermal Eng. Conf., 3(1992), 267.

(19) Yoshida, T. and Akashi, K., J. Appl. Phys., 48(1977), 2252.

(20) Patankar, S. V., Numerical Heat Transfer and Fluid Flow, (1980), 126, McGraw-Hill. 